\title{
A COMPARATIVE ANALYSIS OF TAKEOVER REGULATION IN THE EUROPEAN COMMUNITY
}

\author{
DAVID J. BERGER*
}

\section{INTRODUCTION}

There can no longer be any question that Europe has gained the attention of U.S. business. Many of the largest and best known U.S. companies, including such household names as Hewlett-Packard, Phillip Morris, and AT\&T, are increasingly looking to Europe as their largest potential growth market in the 1990s. ${ }^{1}$ Perhaps even more significantly, the drive to expand sales and operations within Europe has been especially great among the fastest growing companies in the United States. For example, of the twenty Silicon Valley companies recently named to Fortune magazine's list of America's 100 fastest growing companies, more than half receive between one-third and one-half of their revenues from international operations. Moreover, many of these companies (and their competitors) claim that international operations, particularly revenues in Europe, represent the best opportunity for growth in the decade ahead.

The drive to expand in Europe has been spurred, at least in part, by the European Community's ("EC") proposed unification by the end of 1992. U.S. companies are well aware of the "carrot and stick" contained within the unification program: a company that enters any EC country prior to 1993 obtains barrier-free access to the world's single largest market, containing more than 340 million consumers, and to one of the world's wealthiest and

Copyright $\odot 1992$ by Law and Contemporary Problems

Associate, Wilson, Sonsini, Goodrich \& Rosati, Palo Alto, California.

This article is based upon a speech given at a conference titled "The Impact of International Regulatory Competition on American Securities Laws," in October 1991, and has not changed significantly since that date to take into account, for example, Maastricht or its rejection. The author would like to thank the participants of the conference, and in particular Professor James D. Cox, Professor Norman Poser, and Waide Warner for their insightful comments and analysis. Responsibility for any errors, however, rests solely with the author.

I would also like to thank Nicola Erbe, an associate at Wilson, Sonsini, Goodrich \& Rosati, and Peter Lefkowitz and Cecil Gill, summer associates at Wilson, Sonsini, Goodrich \& Rosati in 1991, for their assistance, and Larry Sonsini for providing the guidance and leadership which made the article possible.

1. For example, Phillip Morris' $\$ 3.8$ billion acquisition of the Swiss candy maker Jacobs Suchard was the largest acquisition by a U.S. company in the European Community in 1991, accounting for more than $32 \%$ of the total spent by U.S. companies on European acquisitions in 1990. See Jonathan Fuerbringer, Larger Mergers Delayed by War, NY Times D2 col 1 (April 11, 1991); Garrick Holmes, Europe's Agents of Change, Mergers \& Acquisitions 7-9 (May/June 1991). 
best-educated work forces. A company that fails to enter prior to January 1, 1993 risks being excluded from this "fortress Europe," which will impose prohibitive tariffs on products created outside the single market.

Expanding beyond the familiar domestic market entails significant and often unpredictable risks for a company, particularly small or medium-sized companies. Often, such companies find that a significant portion of both their financial and management resources are spent in determining how to enter, rather than how to succeed in the foreign market. Obtaining local expertise and gaining customers who have traditionally relied on local vendors or have historical, linguistic, and cultural ties with local companies can create obstacles, even for companies with superior products.

In an effort to overcome some of these obstacles, many non-European companies seeking to enter or expand operations in the EC consider acquiring or entering into a joint venture with an already established European company, rather than attempting to enter alone. In addition, industry consolidation in the EC remains significantly below U.S. levels, yielding a large number of potential acquisition partners for companies looking to enter or expand in the EC market.

These attitudes have led, in part, to an explosion of cross-border merger and acquisition activity within the EC, notwithstanding the overall worldwide decline in such activity. Cross-border mergers and acquisition activity in the EC reached a new high in 1990-approximately 1500 transactions, with an aggregate value of over $\$ 62$ billion, an increase of more than fifteen percent over 1989-despite the very difficult market for merger and acquisition activity throughout the world. ${ }^{2}$ Particularly noteworthy was the activity of Swedish companies, which were the second most active in terms of deal value and number of transactions; ninety-nine percent of Sweden's total expenditures on mergers and acquisitions went to EC-based targets, demonstrating the determination of companies in this European Free Trade Association ("EFTA") member country to obtain access to the EC market. ${ }^{3}$

Yet, foreign buyers looking to enter the EC market through acquisition continue to face a substantial regulatory burden. While the drive to a single market has led to technical uniformity in a large number of areas, significant differences continue to exist among the EC countries' corporate regulations, particularly regulations governing acquisitions of companies. The EC's attempt to unify takeover regulation within the Community through adoption of a "takeover directive" appears to be failing, further emphasizing the

2. Holmes, Mergers \& Acquisitions at 7-8 (cited in note 1).

3. Id.

4. Proposal for a Thirteenth Council Directive on Company Law Concerning Takeover and Other General Bids, 1990 OJ (C 64) 8 ("Takeover Directive"). The Takeover Directive has been the subject of considerable debate within the EC. For an analysis of the Takeover Directive, as well as a review of recent amendments to it, see David J. Berger, The Second Common Market: Development of a Unified Standard for Reviewing the Actions of Target Directors in the United States and the European Community, 9 Intl Tax \& Bus L 1 (1991).

The Takeover Directive is currently under review by the EC's member states. The Netherlands, which holds the EC presidency until the end of 1991, has been among the strongest opponents of the 
substantial differences existing between EC countries, both on the merits of takeovers and the proper methods for regulating and limiting takeover abuses. Further, the written regulations of individual EC countries are often less important than the custom and practice within the country, or the philosophy underlying the regulatory system. The importance of local customs and relationships is particularly true where the regulations have only recently been enacted in response to EC directives, and in countries such as Germany or Spain that have rarely seen domestic takeovers. ${ }^{5}$

This article seeks to disperse some of the regulatory haze created by the various philosophies of corporate governance within the EC. Understanding the different systems of takeover regulation within the European countries before attempting an acquisition can provide a company with more than just important technical knowledge about the requirements of an acquisition; often, such understanding provides insight into pertinent cultural and historical factors of the particular country, which can assist an acquiror both in determining how to choose a particular target, and in conducting negotiations. Takeover regulation does not grow in a vacuum; the method by which a country decides for regulating corporate acquisitions frequently explains a great deal about how corporations function within the country, and how the broader process is viewed.

This article summarizes, in Parts II, III, and IV, respectively, the mergers and acquisition processes in the United Kingdom, France, and Germany. This summary includes not only the regulatory systems affecting an acquisition, but also the corporate, financial, and market factors that in many European countries are more significant than the actual regulatory regime. ${ }^{6}$

This article focuses on these three countries for several reasons. First, the United Kingdom, France, and Germany have by far the largest economies and stock exchanges, as well as the most active takeover markets in the EC. Second, and perhaps more significantly, the debate now occurring over EC takeover regulations mirrors the decisions made in these three countries since, in many respects, the United Kingdom, France, and Germany are examples of the three different systems of takeover regulation now in place within the EC.

Takeover Directive, making it unlikely that any new action on the Directive will occur before January 1992, when Portugal assumes the EC presidency.

5. Recent studies by the consulting firms Booz-Allen and Coopers \& Lybrand have demonstrated substantial structural and legal obstacles to cross-border mergers and acquisitions. See Booz-Allen Acquisition Services, Study on Obstacles To Takeover Bids In the European Community (1989); Coopers \& Lybrand, Barriers To Takeovers In The European Community (Her Maj Stationery Office, 1989) (a study) ("Barriers"); see also David J. Berger, The European Markets Try To Coordinate, Unify Conficting Merger Law, Natl L J S14 col 1 (Nov 6, 1989) (discussing studies and structural and legal obstacles to takeovers).

6. This article will not discuss the EC's proposed Takeover Directive, or the likelihood that the Takeover Directive will be adopted. The author has previously analyzed in detail the original and amended versions of the Takeover Directive. See Berger, 9 Intl Tax \& Bus L 1 (cited in note 4) (discussing current status of directive); David J. Berger, Exporting the Twin Towers: The Development of a Transnational Business Judgment Rule, 9 SLU Pub L Rev 169 (1990) (analyzing original version of the proposed directive and its potential impact). 
Thus, the United Kingdom, with its highly developed takeover market, has a history of significant regulation, albeit regulation generally created and enforced by non-statutory bodies such as the Panel on Take-overs and Mergers. This system is roughly comparable to that currently in place in Ireland, and is looked upon favorably by those seeking to create or allow an active takeover market within the EC.

France, which has traditionally had little takeover activity, is one of several countries, including Spain, Belgium, Italy, Norway, and Denmark, that have recently introduced or enacted new takeover legislation in connection with an anticipated increase in takeovers after 1992. While these new regulations are, in general, similar in substance to regulations in the United Kingdom, the regulations are statute-based and thus are enforceable in the courts.

The third group, led by Germany but also including the Netherlands and, to a lesser degree, Denmark and Norway (as well as such non-EC European countries as Sweden and Switzerland), has used market and cultural forces to virtually eliminate hostile takeovers. Accordingly, codified or even selfregulatory rules governing takeover activities are limited in scope and generally of less significance. Additionally, the overwhelming number of transactions are consensual, and shareholder concerns are considered to be of secondary importance.

In sum, a better understanding of the takeover regulatory system in these three countries may provide insight into the types of takeover regulations that the EC is likely to adopt over the next several years.

II

\section{The U. K. Method of Takeover Regulation: A System of Non-STATUTORY REgUlation}

Britain has long had the most active takeover market in the EC, as well as a widely respected system for regulating change-of-control transactions. Despite the recent worldwide decline in takeovers, which has also occurred in the United Kingdom, the United Kingdom remains by far the largest takeover market in Europe. Indeed, during the fall and winter of 1991, a number of transactions, including large bids by Hanson for Beazer, BTR for Hawker Siddeley, and Abbey National for Scottish Mutual, have again placed Britain in the forefront of the worldwide merger and acquisition market. ${ }^{7}$

The British system is widely referred to as a "non-statutory" system, emphasizing self-regulation by the securities industry rather than particular legal penalties for violations of specific laws. ${ }^{8}$ This view should not be

7. For an analysis of these three bids, see Return of the Takeover, The Economist 19-20 (Sept 28, 1991); Merger, Mystery, Suspense, The Economist 71-72 (Sept 28, 1991).

8. A number of articles have compared and contrasted the takeover regimes in the United Kingdom and the United States. See, for example, Thomas Hurst, The Regulation of Tender Offers in the United States and the United Kingdom: Self-Regulation Versus Legal Regulation, $12 \mathrm{NC} \mathrm{J} \mathrm{Intl} \mathrm{L} \mathrm{Comm} \mathrm{Reg}$ 389 (1987); Tony Shea, Regulation of Takeovers in the United Kingdom, 16 Brooklyn J Intl L 89 (1990); Deborah A. DeMott, Current Issues in Tender Offer Regulation: Lessons From the British, 58 NYU L Rev 45 
overstated; the U.K. system, based upon the joint cooperation of all the major domestic financial and legal institutions, exacts significant penalties for failure to comply. The penalties are frequently imposed on both the takeover professionals advising and assisting in transactions as well as the principal.

\section{A. Pre-Bid Analysis and Disclosures Required Prior to the Offer}

Two preliminary issues a potential acquiror faces are the availability of information about the target prior to the time the bid is made or the target is approached, and the ability of the bidder to acquire shares of the target prior to disclosing its intent to make an offer.

In the United Kingdom, as in the United States, a significant amount of reliable financial information must be disclosed by a publicly-listed company. For example, all companies with share capital must file an annual report containing certain specified financial information, as well as an annual profit and loss statement and balance sheet, which must disclose additional detailed financial information. ${ }^{9}$ All of this financial information must be audited by the company's independent auditors, who must state that the company's accounts have been properly prepared and present a "true and fair view" of the company's financial position. ${ }^{10}$ In addition, a company whose shares are traded on the stock exchange has a continuing obligation to update prior disclosures and explain any material differences between their results and those contained in any forecast published by the company. ${ }^{11}$ This extensive pool of data allows a potential acquiror to obtain a significant amount of information prior to approaching a target company.

An acquiror may also purchase up to three percent of a public company's issued share capital carrying voting rights before making any disclosures. Once the three percent level is reached, the purchaser must disclose this information within two business days and make additional disclosures whenever the stake is increased by one percentage point. ${ }^{12}$ Any person

(1983). In general, these articles look quite favorably upon the British system, particularly praising it for avoiding tactical litigation and for its fairness to minority shareholders.

9. See Companies Act 1985 ("1985 Companies Act”) at $\$ \S 220-40,363-65$, and Schedules 4, 5 , and 15 (detailing the list of items that must be disclosed and how to maintain records).

10. The principle of "true and fair view" and an explanation of the meaning of this term are contained in the Statement of Standard Accounting Practice ("SSAP"), the basic accounting standard in the United Kingdom.

11. The disclosure obligations for companies listed on the London Stock Exchange are contained in the Stock Exchange Rules For Admission of Securities to Listing, which is commonly referred to as the "Yellow Book" because of its yellow binder. For a detailed listing of the additional disclosure obligations for a public company, see Yellow Book $\$ 5$ ch 1 (1984). See generally $A$ Practitioner's Guide To The Stock Exchange Yellow Book (Westminster Management Consultants Ltd., 1991).

12. 1985 Companies Act $\$ 198$. Section 201 further empowers the Secretary of State to alter the three percent level by regulation, affirmed by Parliament, when appropriate. It was this provision that was used to reduce the threshold level of ownership requiring disclosure from five percent to three percent in 1990 . 
"acting in concert" with the purchaser for the purpose of "acquiring an interest" in the target's shares must also make the required disclosures. ${ }^{13}$

A bidder may face another significant potential disclosure obligation in the United Kingdom. U.K. corporate law provides that a public company may compel a shareholder to disclose information concerning any level of ownership when the company knows or has reason to believe that the shareholder owns or has an interest in the target's shares prior to the date of the disclosure demand. ${ }^{14}$

The United Kingdom also imposes strict limitations on the ability of a bidder, prior to the time an offer is made, to increase his or her ownership of voting securities above fifteen percent. The limitations are set forth in the Rules Governing Substantial Acquisition of Shares ("SARs"), which are issued and administered by the Panel on Takeovers and Mergers ("Takeover Panel"), and are published as part of the City Code on Takeovers and Mergers ("Takeover Code"). ${ }^{15}$ Simply stated, the SARs prohibit any person from acquiring, in any seven day period, shares carrying ten percent or more of the voting rights of a company if the acquisition, when added with any existing holding, would give the acquiror between fifteen percent and thirty percent of the company's voting securities. ${ }^{16}$ The SARs further require disclosure to both the stock exchange and the target company upon the acquisition of fifteen percent of a company's voting rights, as well as any subsequent acquisition that increases the ownership level by one percentage point. ${ }^{17}$

B. Methods for Making, Accepting, and Rejecting an Offer-The Takeover Code

The Takeover Code governs the making of a public offer in the United Kingdom. The Code consists of ten "General Principles" and thirty-eight specific "Rules," which are applicable to all offers. The Takeover Code further provides that it is "impracticable to devise rules in sufficient detail to cover all circumstances which can arise in offers. Accordingly, persons engaged in offers should be aware that the spirit as well as the precise wording of the General Principals and the ensuing Rules must be observed."'18

13. 1985 Companies Act $\S \S 204-07$. See generally Geoffrey K. Morse, Charlesworth's Company Law 254-61 (Stevens, 13th ed 1987) (discussing cases and definition of "acting in concert").

14. 1985 Companies Act at $\$ 212$. In addition, shareholders may compel the company to investigate and report on any shareholder owning ten percent or more of a company's equity.

15. The SARs were introduced in 1981 to restrict the so-called "dawn raids," when substantial acquisitions of shares were made from large shareholders prior to the time small shareholders could sell their shares.

16. SARs Rule 1. The actions of a shareholder owning more than $30 \%$ of a company's voting securities are regulated by the Takeover Code.

17. Id at Rules 2-3.

18. Takeover Code, GP 1. The Panel has decided that there can be a breach of the Takeover Code without a violation of any specific provision. See, for example, Panel Statement, Johnson \& Firth Brown Ltd. v. Dunford \& Elliot Ltd., $1977 \mathrm{~J}$ Bus L 161; see generally Geoffrey K. Morse, United Kingdom, in Harold Bloomenthal, ed, International Capital Markets and Securities Regulation \$§ 6.01-.04 (Clark Boardman Callaghan, 1991). 
1. Timing of the Offer. The Takeover Code requires that all offers initially be kept open for at least twenty-one days. If there is an increase in offering price or another material change, the offer must be kept open for at least an additional fourteen days. ${ }^{19}$ Offers are generally conditioned upon the bidder obtaining at least fifty percent of the target's voting rights; this condition must be satisfied within sixty days of the date on which the initial offer was made. If this condition is not satisfied, the offer must expire, and the bidder (as well as anyone acting in concert with the bidder) is prohibited from making a new offer within twelve months of the expiration of the original offer. ${ }^{20}$

\section{Price Considerations and Bidding Structures. The Takeover Code contains} significant rules concerning the pricing and structure of a bid. For example, the initial offering must be a price equal to or higher than the highest price paid by the bidder for any of the target's shares purchased in the prior three months. ${ }^{21}$ If the bidder acquires shares in the target during the pendency of the offer at a price higher than the offering price, then it must both immediately disclose the terms of the transaction and increase the offering price to equal or exceed that paid in the transaction. ${ }^{22}$ If the bidder has acquired more than ten percent of the target's voting securities in the twelve months prior to making the offer, the offer must include a cash alternative at a price equal to or greater than the highest price paid by the bidder. ${ }^{23}$

In sharp contrast to the provisions of the Williams Act in the United States, the Takeover Code also contains a mandatory offer provision and generally prohibits partial bids. The mandatory bid rule requires any person who acquires more than thirty percent of a target's voting securities to make an offer for all of the voting shares of the target. ${ }^{24}$ The offer must be unconditional, except that the bid may be conditioned upon the offeror receiving fifty percent or more of the target's stock in the offer. ${ }^{25}$ A bid for more than fifty percent, but less than all, of the target's shares may only be made with the Takeover Panel's consent. The Panel has indicated that it will not normally give consent. ${ }^{26}$ In addition, any offer that could result in the bidder owning between thirty percent and fifty percent of the target's voting

19. Takeover Code Rule 31 .

20. Id at Rule 35. Offers are also required to lapse if the offer is referred on antitrust grounds to the Monopolies and Merger Commission ("MMC") or if the EC issues a decision under Article 8 of the EC merger regulation. A new offer, however, may be made within 21 days following clearance from these authorities. See id at Rules 12, 35.

21. Id at Rule 6 .

22. Id.

23. Id at Rule 11. See also Panel Statement, Hillsdown Holdings plc. v S. \& W. Beresford plc., $1986 \mathrm{~J}$ Bus L 407 (the Panel has discretion to waive this provision where appropriate).

24. Takeover Code Rule 9. The "acting in concert" provision of this Rule has been the subject of particular controversy and is the subject of approximately eight pages of commentary to the Rule.

25. Id. A mandatory offer must be in cash or accompanied by a cash alternative at a price not less than the highest price paid during the preceding 12 month period by the bidder. Id.

26. Id at Rule 36 . 
stock must be conditioned on the approval of stockholders representing a majority of the remaining voting shares. ${ }^{27}$

The Takeover Code also places far more severe limitations on an offeror than does the Williams Act in the United States. In particular, the Takeover Code requires that an offeror should announce an offer only where the offeror believes it will be able to implement the offer in full. In a cash offer, this means that the offeror should have the cash available at the time the offer is made. ${ }^{28}$ Where the financing is being provided through a loan, the loan must not be subject to significant conditions, and the conditions must all be disclosed in the offer document.

3. Duties and Obligations of the Target Board. The Takeover Code places a number of restrictions on the ability of a target board to frustrate a bid. In particular, the board is prohibited from taking any action "during the course of an offer, or even before the date of the offer, if the board ... has reason to believe" that the action could frustrate, deter, or otherwise prevent the target's shareholders from receiving the offer ${ }^{29}$ Rule 21 specifically prohibits the target board from issuing new shares, selling assets, or entering into a contract (other than in the ordinary course of business) when an offer is "imminent." In addition, the Takeover Code provides that if the target board provides information to one bidder, it must provide the same information to all bidders. ${ }^{30}$

There has been extensive litigation to define the scope of the prohibition on director conduct. For example, in connection with recent bids by Minorco for Consolidated Gold Fields and Hoylake for BAT Industries, the Panel sharply limited the ability of a target board to commence regulatory or legal actions against the alleged illegal activity of the acquiror. ${ }^{31}$ As a result of rulings by the Takeover Panel in these offers, it is now clear that litigation by the target against the bidder will be considered a violation of the Takeover Code. ${ }^{32}$

27. Id.

28. In contrast, the Williams Act does not require that a bidder have financing arranged prior to, or even after, an offer is ąnnounced. See, e.g., IU International Corp. $v N X$ Acquisition Corp., $840 \mathrm{~F} 2 \mathrm{~d}$ 220, 221 (4th Cir), aff'd per curiam, 840 F2d 229 (4th Cir 1988) (en banc) (Williams Act does not require a bidder to have financing in place prior to completion of offer); Newmont Mining Corp. $v$ Pickens, 831 F2d 1448, 1453 (9th Cir 1987) (same).

29. Takeover Code Rule 21; see also id at GP 7.

30. This provision inhibits the ability of a potential acquiror, even in a negotiated, friendly transaction, from obtaining access to certain information which would typically be available in similar circumstances in the United States. Id at Rule 20. This provision takes on special importance in the case of management buy-outs. Id.

31. See Panel Statement Minorco plc. v. Consolidated Gold Fields plc. May 9, 1989; Appeal Committee Statement on Hoylake Investment Ltd. v. BAT Industries plc., Sept 29, 1989.

32. See id. A target may, however, lobby government in an attempt to defeat the offer. See generally John K. Grieves, Take-over Regulation in the United Kingdom: An Introduction, in Takeovers: Operating in the New Environment 277-80 (ALI-ABA, 1990). 


\section{Future Trends}

Underlying the United Kingdom's Takeover Code is a philosophy of substantive fairness to all participants, including the bidder, the target, the target's shareholders, and even the public. The Code attempts to meet this goal by closely regulating the market for corporate control. Accordingly, there are high barriers to entering the market including, as described above, strict limitations upon the conditions an offer may have, the length of time the offer may be extended, and the ability of an offeror to acquire a significant minority interest at the expense of small shareholders. Similarly, the United Kingdom prohibits many defensive actions by target management, including unduly favoring one bidder over another.

One effect of these regulations is to limit the number of participants who can gain control of companies in the United Kingdom. For example, it is highly unlikely that many of the financial entrepreneurs who participated in the U.S. takeover market in the 1980 s could have played the same role in the United Kingdom. More generally, it is difficult to effect a successful highlyleveraged offer in the United Kingdom, and it is not possible to make an offer conditional upon obtaining financing. ${ }^{33}$

The U.K. regulatory system also limits the types of acquisitions that can occur. For example, the "junk-bond," highly-leveraged deals that were popular in the United States in the late 1980s were never successful in the United Kingdom. ${ }^{34}$ As a result, the United Kingdom did not experience the many large bankruptcies that occurred in the United States following some of these transactions. ${ }^{35}$

The strengths of the U.K. system-in particular its ability to allow an active takeover market while limiting the perceived financial and legal abuses resulting from the U.S. regulatory system-have led many European observers to view the U.K. system as a model. Accordingly, the U. K. takeover rules have, in many respects, formed the theoretical basis for much of the EC's proposed takeover regulation. In particular, the substantive rules regarding disclosure, mandatory bids, and the role of target directors, which are contained in the most recent draft of the EC's proposed Takeover Directive, are very similar to those contained in the Takeover Code.

At least one important difference remains, however, between the Takeover Code and the proposed Takeover Directive (and the Williams Act): the Takeover Code is the only regulatory system not based on statute, and whose rules are enforced by self-regulatory organizations rather than in the courts. It is not clear whether this self-regulatory system, despite its strong support

33. Perhaps the most noteworthy of the U.S.-style leveraged deals in Europe was Sir James Goldsmith's bid for B.A.T. Industries plc. See Richard A. Melchner, Nothing Is Sacred, No One Is Too Big, Business Week 44 (July 31, 1989). Goldsmith's bid eventually failed.

34. Id. See also Appeal Committee Statement on Hoylake Investment Ltd v B.A.T. Industries, plc. (Sept 29, 1989).

35. For a recent analysis of the problems that could occur with leveraged transactions, see Credit Lyonnais Bank Nederland v Pathe Communications Corp., CA No 12150 (Del Chanc 1991) (Allen, Ch) (analyzing the failed buyout of MGM by Giancarlo Paretti). 
within the United Kingdom and among many who have been involved with or analyzed the U.K. system, can be maintained when virtually every other EC country insists upon a system of statutory regulation, and a public, governmental organization to enforce these regulations.

\section{III}

\section{France: A Paradigm for EC Takeover Regulation?}

Over the last several years, France has developed one of the EC's most active takeover markets, as well as the largest stock exchange on the European continent. The growth of French capital markets resulted in French companies being the largest cross-border acquirors of EC businesses in both 1989 and 1990 , with total purchases in 1990 alone of more than $\$ 13$ billion. ${ }^{36}$ The lengthy list of major French acquirors in 1990 included such well-known companies as Renault, LVMH, Elf Acquitaine, Credit Lyonnais, and Cie Générale des Eaux. During this same period, the domestic market capitalization of the Paris stock market ("Bourse") has also grown considerably, from less than $\$ 120$ billion in 1987 to more than $\$ 190$ billion by the end of 1988 , and more than $\$ 200$ billion in $1990 .^{37}$

France has also undergone a number of substantial changes in its takeover regulations over the last several years. Perhaps most significant was the adoption of France's first takeover law, Law No. 89-531 relating to the Security and Transparence of the Financial Markets ("Law 89-531"), and subsequent regulations promulgated by the two bodies principally responsible for overseeing the French securities markets, the Conseil des Bourses de Valeurs ("CBV") and the Commission des Operations de Bourse ("COB"). ${ }^{38}$ As described more fully below, the new regulatory regime grafts several aspects of the U.K. and U.S. takeover systems onto a continental European economy with a historical distrust of takeovers. Both the flurry of increased takeover activity and the new legal rules governing such activity have resolved in questions concerning the scope of permitted activities, as historical relations among shareholders create new obligations as a result of the new laws. ${ }^{39}$ The changes are likely to continue in response to both new

36. See Holmes, Mergers \& Acquisitions (cited in note 1). See also David J. Berger, Buying Up Europe in New Buyout Regime, Legal Times $26 \mathrm{col} 1$ (Feb 4, 1991) (discussing growth of French companies in international takeovers).

37. David J. Berger, Guidelines for Mergers and Acquisitions in France, 11 Nw J Intl L \& Bus 484, 487 (1991)

38. Law No 89-531 of August 2, 1989, [1989] JO 4 Aout at 9822 ("Law 89-531"). The principal implementing measures, set forth in the Arretes of Septembre 28, 1989, [1989] JO 30 Septembre at 12,301 and 12,307 ("September 28 Regulations") [1989] JO 1 Août at 9,676, include Title V of the General Regulation of the CBV, and COB Regulation No 89-03 ("Regulation 89-03"). The law was, in general, upheld by France's constitutional council. See Decision No 89-260DC of the Constitutional Counsel of July 28, 1989. For a detailed discussion of French Securities Market and the new laws relating to takeovers, see Berger, $11 \mathrm{Nw} \mathrm{J} \mathrm{Intl} \mathrm{L} \mathrm{\&} \mathrm{Bus} \mathrm{at} \mathrm{506-22} \mathrm{(cited} \mathrm{in} \mathrm{note} \mathrm{37).}$

39. According to the director of the $\mathrm{CBV}$, this uncertainty and confusion is shared by the regulators attempting to enforce these new regulations. See David J. Berger, Takeover Activity May Grow, Natl L J 23 (Dec 23, 1991). 
EC developments and as French regulators begin enforcing and interpreting the new rules.

\section{A. Pre-Bid Analysis and Disclosures Required Prior to the Offer}

The disclosure obligations for French companies have increased significantly over the last several years, and this trend is likely to continue. French companies listed on a stock exchange must publish annual financial statements, including profit and loss statements, consolidated financial statements, and portfolio holdings, within four months of the end of the company's fiscal year. ${ }^{40}$ Public companies must also publish as well as quarterly unaudited revenue totals for the company and each subsidiary, biannual operating results, which must be reviewed by the company's auditors. In addition, information concerning the salaries of company's top executives and any reports of the company's statutory auditors must be disclosed to shareholders. ${ }^{41}$

It is worth noting that at least one authoritative source has questioned the reliability of the audited accounts of French companies, particularly where the auditor is not one of the leading international accounting firms. Specifically, Coopers \& Lybrand, in a 1989 report for Britain's Department of Trade and Industry, noted the following:

In our experience, significant adjustments to the published results and net assets may need to be made by [a U.K. or U.S.] acquiror to bring French accounts into an equivalent basis. These adjustments cannot, in general, be qualified without access. Further independent investigation of the accounts can often bring to light material misstatements ... due to the lack of an adequate audit. ${ }^{42}$

A potential acquiror's disclosure obligations in France may vary according to a company's charter, the number of shares owned, and the purpose of the ownership. ${ }^{43}$ Thus, a company's charter can require disclosure following the purchase of as little as 0.5 percent of a company's voting securities; such well known companies as BSN and LVMH have adopted charter provisions requiring disclosure at a one percent threshold. To whom, and within what time, disclosure must be made, may also generally be established in the charter.

In addition to the particular charter provisions, Law 89-531 requires various public disclosures of a purchase of voting securities in a French company at the following levels: five percent; ten percent; twenty percent; thirty-three percent; fifty percent; and 66.66 percent. $^{44}$ Disclosure to the

40. Berger, $11 \mathrm{Nw} \mathrm{J} \mathrm{Intl} \mathrm{L} \mathrm{\&} \mathrm{Bus} \mathrm{at} \mathrm{494-96} \mathrm{(cited} \mathrm{in} \mathrm{note} 37$ ).

41. Id.

42. Coopers \& Lybrand, 2 Barriers at 10 (cited in note 5).

43. Law No 66-537 of July 24, 1966, [1966] JO 26 Juillet at art 356 ("Law 66-537"). The principal regulations governing French business organizations are contained in Law 66-537 and Decree No 67-236 of March 23, 1967, [1967] JO 24 Mars at 2843 ("Decree 67-236"). For a discussion of these two provisions, see Berger, $11 \mathrm{Nw}$ J Intl L \& Bus at 488-505 (cited in note 37); see also George A. Bermann, Henry P. DeVries \& Nina M. Galston, French Law-Constitution and Selected Legislation 24-42 (Transnational Publications, 1990) (partial English translation of the codes).

44. Law 89-531 at art 17 . 
company must be made within fifteen days of the acquisition. If the company's shares are publicly traded, disclosure must be made to the CBV within five market days. ${ }^{45}$ Law 89-531 also introduced the "acting in concert" standard to France, expanding the disclosure requirement to individuals or groups working for a common purpose. ${ }^{46}$ Substantial civil and/or criminal penalties may be imposed for failing to comply with the disclosure provisions. For example, shareholders who fail to comply may have their securities' voting rights suspended for at least two years after the proper disclosure is made, plus face potentially significant fines. ${ }^{47}$

\section{B. Methods for Avoiding or Deterring an Offer-The Use of Pre-Bid Defensive Techniques}

As discussed in more detail below, a French company's defensive options after a tender offer is made are now substantially limited. The post-offer limitations on defensive tactics, though stringent, are not expected to open the French takeover market dramatically nor make French companies more vulnerable to hostile acquisition. This is because many French companies, like their counterparts elsewhere on the continent, have historically relied upon a variety of defensive measures designed to deter a bid by limiting the possibility that an offer will succeed.

Among the most common and successful pre-offer defensive techniques is the use of cross-shareholdings of friendly shareholders to maintain a substantial portion of a company's equity. For example, Coopers \& Lybrand estimated in 1988 that up to fifty-seven percent of the 200 largest French companies were controlled by family groups or other select groups of shareholders; this percentage was found to be even higher for smaller companies. ${ }^{48}$ Similarly, in an attempt to protect a number of newly privatized French companies from unsolicited or hostile bids, the French government frequently sold a significant block of stock to "hardcore friendly shareholders" ("noyau dur"). As a result of this policy, it is estimated that as much as thirty percent of the equity of the largest French companies is owned by various noyau dur, who are obliged to retain these holdings for a specified time, and who may only sell their holdings to specified groups of individuals and companies. ${ }^{49}$

Another popular defensive technique for French companies is to issue super voting or non-voting stock. For example, the charters of such major French companies as Piper-Heidseck, Peugeot, and LVMH all provide that

45. Id at art 18

46. Id at art 17. The "acting in concert" standard has been an issue of considerable controversy following the CBV's recent ruling that Bollore was acting in concert with Clinvest and El Rabha to acquire the French shipping company Delmas-Vieljeux. See notes 60-62 and accompanying text.

47. Law 89-531 at art 20 .

48. Coopers \& Lybrand, Barriers at 15 (cited in note 5).

49. Id. For a more detailed discussion concerning the effectiveness of the noyau dur policy and its implications, see Berger, $11 \mathrm{Nw} \mathrm{J}$ Intl L \& Bus at 502-04 (cited in note 37); see also Bertrand Jacquillat, Nationalization and Privatization in Contemporary France, 1987 Govt Union Rev 21. 
long-term shareholders have additional voting rights. ${ }^{50}$ It is also possible, although officially discouraged, for a company to place an absolute limit on the amount of voting power held by any one shareholder. Thus, PernodRicard prohibits a shareholder from controlling more than thirty percent of the voting rights of the company, regardless of the number of shares held. ${ }^{51}$

The extensive use of these and other defensive tactics historically allowed a small group of shareholders to maintain control of the company, regardless of the amount of a company's equity they actually owned. This fact led, in turn, to very few hostile bids since the bid could not succeed in the face of opposition from the controlling shareholder(s). While this is beginning to change, a number of the best-known French companies still remain virtually impregnable to unwanted acquisition because of the equity blocks owned by friendly shareholders.

\section{Making, Accepting, or Rejecting a Formal Offer}

The French rules governing the making of a tender offer, though appearing reasonably similar to the Takeover Code and the Williams Act, are in some respects significantly different from both regulatory regimes.

A tender offer commences when the bidder files an application with the CBV. ${ }^{52}$ The application must include the material terms of the transaction and information on the bidder. ${ }^{53}$ Further, application can only be made by the bidder's banking or financial institution, which must guarantee the financing arrangements for the offer. ${ }^{54}$ The CBV automatically suspends trading in the target (and the bidder if it is publicly listed) for a minimum of two days. The CBV must issue a decision concerning the offer within five business days of its filing. The CBV may require the bidder to revise the terms of its offer, or even to post sufficient cash and/or securities to guarantee the financing for the bid. ${ }^{55}$ At the same time, the bidder must file a draft prospectus with the $\mathrm{COB}$, which also must respond within five business days.

1. Timing of the Offer and Competing Bids. As under the Williams Act, a tender offer must remain open for at least twenty days. Competing bids may be submitted until ten calendar days before the original bid is scheduled to close. ${ }^{56}$ The CBV will then extend the duration of the first offer so that both offers close at the same time. Competing cash offers must ordinarily be at a price of at least 102 percent of the prior offer, though no increase is required when the original offer was a partial offer and the competing bid extends the

50. The statutory authorization for such provisions is Law 66-537 art 175. See generally Berger,

$11 \mathrm{Nw} \mathrm{J}$ Intl L \& Bus at 502-06 (cited in note 37).

51. Id.

52. September 28 Regulations art 5 (cited in note 38 ).

53. Id.

54. Id.

55. Id

56. Id 
number of shares being sought. ${ }^{57}$ After ten weeks the CBV may set a deadline for the submission of final bids.

2. Mandatory Tender Offers. Law 89-531 established mandatory tender offers in France. ${ }^{58}$ Under the new regulation, an offeror must bid for at least twothirds of the target's outstanding voting stock upon obtaining thirty-three percent of the target's capital shares. ${ }^{59}$

This provision has become highly controversial after the CBV's groundbreaking ruling that Bollore, a French transport and industrial group, was required to make a tender offer to acquire all of Delmas-Vieljeux, a leading French shipping company. ${ }^{60}$ The ruling was striking because no single investor had acquired the thirty-three percent necessary to invoke the mandatory tender offer provision. Nonetheless, the CBV determined that in acquiring 59.2 percent of Delmas, Bollore had acted in concert with two other investors, a holding company called El Rabha and Clinvest, the investment banking subsidiary of state-owned credit Lyonnais, as well as the main shareholder in El Rabha and Bollore's investment bank. ${ }^{61}$ Accordingly, the CBV required Bollore to offer to purchase all of Delmas' outstanding stock, a decision which cost Bollore more than $\$ 200$ million. ${ }^{62}$

The CBV's ruling in Bollore, as well as a prior ruling in which it required Galeries Lafayette to make an offer for rival retailer Nouvelles Galeries in a transaction involving the issue of double voting rights, indicates that the CBV's interpretation of the new takeover rules will continue to cause considerable uncertainty. ${ }^{63}$

More generally, the CBV's decision also indicates that banks can be considered to be acting in concert with their clients. ${ }^{64}$ This position will have a substantial impact on the way French banks and companies conduct their business for several reasons. The rules will affect the French banks' historical

57. Id.

58. For a discussion of the circumstances giving rise to the adoption of mandatory tender offers in France, see Berger, $11 \mathrm{Nw} J$ Intl L \& Bus at 519-20 (cited in note 37).

59. September 28 Regulations art 3 (cited in note 38 ).

60. See William Dawkins, Small Interests Find Big Voice-France, Fin Times 4 (June 20, 1991) ("Small Interests"); George Graham, Momentum for Growth-France, Fin Times 6 (June 28, 1991); George Graham, Turmoil in the French Business World, Fin Times 26 (June 17, 1991).

61. See Dawkins, Small Interests (cited in note 60); Berger, Natl L J (cited in note 39).

62. Similar issues have recently been raised in a number of French acquisitions, including the acquisition of the leading French department store chain Nouvelles Galaries by its rival Galaries Lafayette, and the bid by Accor the leading hotel group for Wagon Lits, the Franco-Belgian travel group. For a more detailed discussion of these two transactions, see Berger, Natl L J (cited in note 39) (analyzing the CVB's ruling in Nouvelles Galaries and the consequences of the decision); Dawkins, Small Interests (cited in note 60) (reviewing the Wagon Lits deal).

63. See Berger, Natl L J (cited in note 39) (discussing the CBV's ruling in Nouvelles Galaries).

64. Contrastingly, in Paribas' recent attempt to acquire Compagnie de Navigation Mixte ("Mixte"), Paribas complained about the parallel action taken by certain shareholders friendly to Mixte, arguing that additional disclosure about these activities was necessary. In response, the stockholders denied that they had an obligation to disclose their intentions because no written agreement existed among them or with Mixte, a position which was subsequently upheld by the CBV. See generally Steven Marquardt, Tender Offers in France: The New Rules, 1990 Int Fin L Rev 35, 36-37 (Jan 1990). 
practice of holding large equity positions in their clients, a trend that increased in popularity with both the privatization drive and the rising French stock market in the late 1980s. In addition, a number of French banks and companies that are in the midst of large restructurings in an effort to consolidate control and remove excess layers of holding companies will also be affected. As such transactions increase in popularity, there is a corresponding increase in the probability that there will be conflicts between majority and minority shareholders seeking to invoke their new protections.

3. Post-Offer Defensive Maneuvers. A board is severely constrained in adopting or implementing defensive measures after an offer has been made. The COB must be notified in advance of all actions outside the scope of ordinary business while an offer is pending, and such actions are generally prohibited. The target board must consider shareholders' interests paramount, and should demonstrate "particular prudence" in redeploying assets or entering into other extraordinary corporate transactions. ${ }^{65}$

A target board's ability to take defensive action is also increased by Law 89-531, which allows shareholders of a public company to give advance authorization, within certain limits, to a board to issue new shares, even while an offer is pending. ${ }^{66}$ The most significant new provision allows a company to issue new shares during a tender offer, without having to wait the normally lengthy time periods necessary for approval of a capital increase. In this way, a target board can potentially increase the cost of an unwanted offer by increasing the number of shares outstanding, as well as possibly increasing the shares owned by friendly shareholders. The usefulness of this provision as a defensive maneuver is limited, since it circumscribes the board's ability to waive preemptive rights with respect to the newly issued shares.

4. Future Trends. France is likely to remain one of the most active merger and acquisition markets on the European continent, increasingly being viewed as a guide for those EC countries attempting to develop a new takeover system. France's new takeover regulatory system is particularly noteworthy because, although statutorily based, it has not resulted in the significant growth in "tactical" litigation that is a common feature in the U.S. takeover system. The creation of a statutory system, which has opened up the French market for takeovers, has not yet led to a litigation or financial explosion, and has made France's system an intriguing model for other continental countries seeking to develop their own regulatory systems, especially those countries which lack the strong self-regulatory traditions that form the basis of the U.K. system.

The French system has its critics. Perhaps most vocal are minority shareholders, who have been the perceived victims in a number of recent large French bids, including: Pinault's offer to purchase Au Printemps, the

65. Regulation 89-03 at art 3 (cited in note 38 ).

66. Law 89-531 at art 14 (cited in note 38 ). 

(Aktiengesellschaft or "AG"), the most common form of business enterprise for large German businesses, means that even a majority stockholder will have a difficult time obtaining control over the company. Third, the role of the banks in financing growth has resulted in the banks becoming substantial investors in, and supporters of, management, as well as the fact that the banks having greater control than their nominal share ownership would indicate, in part because a bank representative often sits on the board of the company, and because banks often are proxies for shareholders, with discretion to vote the shares as the bank determines. Fourth, there is a relatively small base of institutional investors who may be tempted by an offer at a premium. Finally, various German legal principles deter large debt-financed transactions by, for example, prohibiting an AG and, to a lesser degree, a limited liability company (Gesellschaft mit beschrankter Haftung or "GmbH") from pledging its assets to finance, directly or indirectly, the purchase of its shares. ${ }^{72}$ When these factors are combined with a relatively lax corporate governance system that allows disparate voting rights for shareholders, the German system can look impregnable to a foreign investor.

This view is wrong. Acquisitions are occurring in Germany, and are likely to increase in both size and frequency over the next several years. ${ }^{73}$ Moreover, from a regulatory standpoint, the German market contains virtually no limitations on even so-called "abusive" takeover tactics; indeed, Germany does not even have laws prohibiting insider trading, nor is a single regulatory agency responsible to oversee the market. ${ }^{74}$ Thus, in many ways Germany presents a unique opportunity for even unsolicited acquisitions.

\section{A. Pre-Bid Analysis and Disclosures Required Prior to the Offer}

Obtaining basic financial information about a German target can be difficult. While companies must publish financial statements and public companies must publish additional information, including a semi-annual financial report, small and medium-sized German companies, often the type of company most likely to attract foreign interest, have only limited disclosure obligations. Moreover, many of the disclosure obligations now in place result from various EC directives. It is not clear what penalty, if any, will be imposed for noncompliance or incomplete or inaccurate disclosures. ${ }^{75}$

72. See German Public Stock Corporation Act $\$ 57$, ๆ 1 (Aktiengesetz or “Aktg") (1988). See also Maximilian Schiessl, Leveraged Buyouts In Germany, 1991 Int Bus L 305; Eckart Wilcke, Germany, in International ME'A: A Guide to the Regulation of Mergers and Acquisitions Worldwide, 1991 Int Fin L Rev 49.

73. For a view that the German takeover market is perhaps the most open European market, see Hans-Jochen Otto, Obstacles to Foreigners Are Nothing But A Myth, Fin Times 15 (Feb 20, 1991).

74. Germany's failure to adopt laws prohibiting insider trading has resulted in much criticism of the German stock markets, particularly in light of recent scandals involving alleged improprieties by members of Dresdner Bank in the new issues market. See Katharine Campbell, German Stock Scam Prompts Tighter Rules, Fin Times 3 (Sept 19, 1991); Sweeping Out the Stables, The Economist, 15 (Aug 31 , 1991). For a more detailed analysis of Germany's attitude toward insider trading, see Joseph Blum, The Regulation of Insider Trading in Germany: Who's Afraid of Self-Restraint, 7 Nw J Int L \& Bus 507 (1986).

75. See Coopers \& Lybrand, Barriers at 10-15 (cited in note 5). 
In addition, the disclosures frequently must be made only to the company's local Commercial Register, and although the information is then available to the public, the lack of a "central" registry makes access to company information more difficult than in the United States or United Kingdom. ${ }^{76}$

Equally scant disclosures are required of potential acquirors. Perhaps most significantly, there is no disclosure provision comparable to those in the U.K., French, and U.S. takeover codes, all of which require substantial disclosures once an acquiror has purchased between three percent and five percent of a company's equity. In contrast, disclosure of share ownership in Germany is only required when a shareholder owns above twenty-five percent of a company's voting stock or above fifty percent of its nominal capital. ${ }^{77}$ Requiring disclosure only after this significant level of ownership is reached may allow a bidder to gain a significant stake in the target prior to making or announcing any offer. ${ }^{78}$

Moreover, German law does not include the concept of "acting in concert" or "beneficial ownership" when calculating ownership levels. ${ }^{79}$ Because of this, a bidder frequently can avoid violating provisions in a company's charter or by-laws that prevent one entity from voting more than a set number of shares regardless of its stock ownership. This situation occurred in both the Flick brothers' bid for Feldmuhle Nobel AG and in Pirelli's recent effort to acquire Continental. ${ }^{80}$ This type of toe-hold can, however, result in a sharp increase in the share price of the target, particularly given the fact that there are only approximately 500 publicly traded German companies, many of which are either family controlled or controlled by a few dominant shareholders. In fact, one knowledgeable source estimates that there are only approximately thirty German companies that have a sufficiently dispersed shareholder base to allow a hostile bid to be successful. ${ }^{81}$

76. Id.

77. Id at 10-23. See also West Germany, in A Practitioner's Guide To European Takeover Regulation and Practice 329-30 (Westminster Management Consultants, Ltd., 1990) ("West Germany").

78. Where disclosure is required, a shareholder may not exercise the rights of share ownership until the disclosure has been made. This is, however, the only penalty for failing to comply with the disclosure obligations. 77).

79. Coopers \& Lybrand, Barriers at 12-15 (cited in note 5); West Germany at 329-30 (cited in note

80. In the Pirelli/Continental situation, for example, Continental's charter placed a five percent ceiling on the voting rights of Continental shareholders, regardless of the number of shares owned by a shareholder. To defeat this limitation, Pirelli and its advisers (principally Morgan Stanley, Merrill Lynch, and Media Banca) created a shareholder pact, pursuant to which each member would buy up to five percent of Continental's stock. As part of this agreement, Pirelli agreed to cover any losses suffered by any of its allies as a result of their ownership of Continental stock, while the allies agreed to vote with Pirelli to replace Continental's supervisory board, if necessary. See generally Simonian, Fin Times (cited in note 70 ).

81. Wilcke, 1991 Intl Fin L Rev at 49 (cited in note 72). 


\section{B. Structural Defense for Deterring an Offer}

When considering an acquisition of a German company, the first issue a non-German bidder must consider is how to structure the approach. This will be determined, at least in part, by the structural defenses which the company has in place. The most significant of these structural defenses are summarized below.

1. Two-Tiered Boards. All AGs (as well as larger GmbHs) must have a twotiered board structure. Under this structure, day-to-day control over the company rests with a management board (Vorstand). The members of the management board are appointed by a separate, second-tier supervisory board (Aufsichtsrat). Management board members are typically appointed for five year terms, and cannot usually be removed prior to the completion of this period except in the case of fraud or illness. Management board members cannot be removed directly by shareholders, and are not voted upon by shareholders, although some companies do provide that loss of shareholder confidence can be cause for removal. The management board's duties are to the corporation as a whole rather than to shareholders. ${ }^{82}$

Members of the supervisory board are selected by shareholders and employees. All AGs and any $\mathrm{GmbH}$ with more than 500 employees must seat employee representatives in at least one-third of the places on the supervisory board. Large companies (defined as those with more than 2000 employees) must provide for equal representation of employee and shareholder representatives. The chairperson of the supervisory board, who is elected by shareholders, retains the ability to cast a "second" vote in the event of a tie vote on any matter. A company may (and many German companies frequently do) provide that removal of a supervisory board member requires a super-majority vote of stockholders, and may also provide that particular shareholders (or classes of stock) have the right to designate up to one-third of the members of the supervisory board. ${ }^{83}$

The two-tier board can be a significant deterrent to a bid in several ways. First, it means that even a majority stockholder cannot immediately exercise control, since a majority shareholder often cannot replace a majority of the supervisory board, while management board members-the group who actually runs the company on a daily basis-cannot be removed until the expiration of their five-year term of office. Second, since many supervisory boards allow for a removal of members only upon a vote of seventy-five percent of the shareholders, an acquiror will often need to acquire more than a simple majority of shares to even remove supervisory board members. Finally, since management board members are largely insulated from shareholders, the management board may (and frequently does) take action to frustrate a bid that shareholders may wish to accept (or at least consider).

82. See generally West Germany at $316-20$ (cited in note 77 ).

83. Id. 
2. Restricted Voting Rights. A second significant structural defense is the use of restricted voting rights to limit the number of votes a single shareholder may exercise. The by-laws of many German companies limit the number of votes a single shareholder may exercise to five or ten percent of the company's total voting rights. In addition, cross-shareholdings are fairly common, although the German Stock Corporations Act limits the votes that may be cast by an AG to twenty-five percent even if the holding in the other enterprise in the AG exceeds twenty-five percent.

Recent events have indicated, however, that the lack of an "acting in concert" principal may make restricted-voting rights less effective than had previously been thought. For example, both Pirelli and the Flick brothers avoided their targets' restricted voting limitations by arranging for groups of friendly investors to make the acquisitions. These separate groups then apparently agreed to vote their shares in accordance with the instructions of the potential acquiror.

3. Super-Majority Requirements. AGs and GmbHs are both permitted to have super-majority requirements in their articles. Such requirements can apply, for example, to the removal of a supervisory board member, to the amendment of the articles, or even to the acquisition or disposition of certain assets. These provisions, particularly when coupled with restrictive voting rights, may prevent even a majority stockholder from selecting the supervisory board or changing the direction of a company.

4. Dependent Companies and Control Agreements. One of the most difficult concepts for a U.S. or U.K. purchaser to understand when considering an acquisition in Germany is the strict limitations placed on a majority or controlling shareholder. For example, when an AG is controlled by a single legal enterprise, the management board of the controlled AG must produce an annual "dependency report" detailing any transactions between the controlling and controlled enterprises, and confirming that the transactions, taken as a whole, were fair. The auditors and supervisory board must confirm the dependency report; a shareholder may obtain a court-ordered audit if the dependency report is either not ratified or if the dependency report states that unfair transactions occurred. These provisions can provide substantial authority for limiting the effectiveness of a majority shareholder's control, particularly to employee representatives on the supervisory board. ${ }^{84}$

A dependency report may be avoided where the AG enters into a "control agreement" with the controlling shareholder. A control agreement requires the approval of seventy-five percent of the shareholders, and minority shareholders must be given an opportunity to either sell their shares or receive a guaranteed dividend, providing fair value, when a control agreement is entered. While a control agreement allows the controlling shareholder to bypass the supervisory board and give direct instructions to the management

84. Id at 318-19. 
board, the controlling shareholder becomes jointly and severally liable for all direct and contingent debt incurred during the term of the control agreement.

\section{Making, Accepting, or Rejecting an Offer}

Currently, no binding rules govern the takeover process in Germany. The effective rules, which are voluntary guidelines, were promulgated in 1979 by the Stock Exchange Committee of Experts, affiliated with the Federal Ministry of Finance, and do not have the force of law, nor are they considered binding upon those making an acquisition. In addition, Germany does not have a single regulatory authority like the Takeover Panel in the United Kingdom, France's CBV, or the SEC in the United States, with the ability to make rulings or decisions in connection with a takeover. The guidelines apply only to AGs or limited partnerships (Kommanditgesellschaft or "KGs") but not to GmbHs or other commercial enterprises. ${ }^{85}$

Besides being voluntary in nature, the guidelines are far less stringent than those of the United Kingdom and France. For example, there are virtually no restrictions on the offeror; partial offers are allowed, the offeror may continue the offer for as long as it wishes and, if unsuccessful, may make another offer at any time. In addition, no disclosure of any beneficial ownership is required; the method of publication and disclosures made in the offer is largely left to the discretion of the offeror, as the offer document does not have to be filed with any regulatory agency.

Similarly, there are very few restrictions on the actions of the target board. The target also does not have to provide the offeror with any information concerning the company or its stockholders: Even if the bidder is a shareholder, its rights to information under German law are limited. Finally, German corporate culture can act as a barrier, since the view that management should have a sense of responsibility for the company and its employees often outweighs any sense on the part of management or shareholders that shareholder value should be maximized. ${ }^{86}$ In particular, the management board of an AG does not owe a separate fiduciary duty to shareholders, and German law does not provide for derivative shareholder litigation. ${ }^{87}$ Further, the concept of shareholder rights or a board acting in the interests of the shareholders, as opposed to the company and its stakeholders as a whole, is foreign to the German market. This lack of a philosophical basis to support maximizing shareholder value allows both

85. For an English translation and summary of the guidelines, see Coopers \& Lybrand, Barriers (cited in note 5 ).

86. This attitude can even be seen where the target company determines that a sale of the enterprise is inevitable. For example, when Maxwell Communications Corporation made a contested bid for Bibliographische Institute and FA Brockhaus AG ("BIFAB"), a principal argument that BIFAB made was that MCC would not be a suitable employer of BIFAB's workers.

87. The only provision allowing derivative-type actions is $\$ 147$ of the Stock Corporation Act, which permits holders of ten percent or more of an AG's voting shares to demand a damage action be brought by and on behalf of the company against members of the management and/or supervisory boards whose acts have injured the company. Aktg $\$ 147$ (cited in note 72). 
management and supervisory boards to take a variety of steps to defeat an unwanted bid.

\section{Future Trends}

The German economic system fundamentally rejects the use of takeovers as a method for restructuring corporations. Instead, the German system relies upon the close monitoring of corporations by banks and others (for example, creditors, employees) with a direct economic interest in the affairs of the corporation. As a result, Germany has developed neither an active takeover market nor a reliable system for regulatory control over corporate transactions.

The structural barriers to takeovers in Germany have also raised the most serious impediments to foreign acquisition of any of the larger EC countries. As described above, the barriers to hostile bids are formidable, and even consensual transactions are difficult, particularly given the historical reluctance of many corporate officers to sell a business to a non-German entity.

Notwithstanding these difficulties, however, foreign acquisitions of German companies can be expected to increase over the next several years. A primary reason for this expected increase is economic: many German businesses, particularly Gmbhs, are still family-owned, with strong cash flow and asset values. The founder, who typically formed the company shortly after World War II, is now ready to retire and no obvious successor is available. Under such circumstances, a sale of the company makes a great deal of financial sense. In addition, the development of the former East Germany and the privatization of many formerly state-run companies have led to a dramatic increase in the number of potential acquisition candidates. Third, there appears to be a trend towards using equity financing in Germany, and this practice could lead to an increase in the number of companies that may be acquired, even on a hostile basis.

\section{$\mathrm{V}$ \\ Conclusion}

This article has briefly analyzed the existing takeover regulations in the three largest EC economies. The United Kingdom, France, and Germany are also the three countries that have taken the lead in developing (and criticizing) the EC's proposed Takeover Directive, and that can be expected to have the most significant impact upon any Takeover Directive ultimately adopted by the EC. Finally, these three countries also have the largest stock exchanges in the EC, and all are currently attempting to establish theirs as the dominant exchange.

There are several important lessons which can be learned from an analysis of the takeover regulations in these three countries: First, even if the EC adopts a uniform takeover directive applicable to all its member-states, there 
will still remain practices that may inhibit the acquisition process. As can be seen from the example of France, imposing a comprehensive takeover regime on a system which has historically had substantial barriers to acquisitions does not create a barrier-free system.

Second, the existence of cultural and political factors unique to a particular country will continue to play an important role in the acquisition process. For example, using a German bank when attempting to make an acquisition in Germany may not only expedite the substantive negotiations, but may also simplify the process of identifying a target and obtaining relevant financial information.

Finally, an understanding of national regulations can often provide an explanation for behavior that seems illogical to a U.S. acquiror. Thus, the reluctance by a British target to provide complete disclosure in a friendly transaction is understandable when it is recognized that the target must then provide the same information to any potential bidder, including competitors.

In sum, U.S. companies can make acquisitions in the EC, even hostile bids. But such transactions must take into account the very different historical and cultural forces that exist in each EC country. Further, when considering how EC regulation is likely to develop in the near future, it is important to focus on the individual positions of the member states, not just the institutional concerns of the various legislative branches of the EC. Finally, it is worth noting the increasing consensus, even in such countries as Germany and the Netherlands, about the need for increased regulation of corporate activity and opening domestic markets. These factors should lead to continued growth in EC takeovers, both domestically and on a cross-border basis. 
